\title{
CRITICAL INFRASTRUCTURE SAFETY AND PROTECTION IN SLOVAK REPUBLIC - RESEARCH AND EDUCATION
}

\section{Zdenek Dvorak}

Faculty of Security Engineering, University of Zilina in Zilina, Zilina, Slovakia

\section{Bohus Leitner}

Faculty of Security Engineering, University of Zilina in Zilina, Zilina, Slovakia

\section{Lenka Mocova}

Institute of Continuing Education University of Zilina, Zilina, Slovakia

\section{OMESTE}

JEL Category: H12, 018, R41

\begin{abstract}
The problem of security and the critical infrastructure protection in the European area is becoming more topical which can be proved by the current security situation in the world. Our society must react to the current security situation and new migration-related issues. One of the challenges we are facing is fostering security research and education in the field of security management in the most important areas of human life. The aim of this paper is to present the generally defined basic terms and aspects of understanding the problem of security and protection of critical infrastructure. Our task is to define the need of education in the field of management of critical infrastructure security. The paper also presents the purpose and contents of the new study programme at the Faculty of Security Engineering of the University of Žilina and its graduate profile. There are also stated some topical problems related to implementing this study programme.
\end{abstract}

Keywords: critical infrastructure, sector, energy, transport, security, protection, new study programme

\section{INTRODUCTION}

The University of Žilina (hereinafter UNIZA) is a higher education and scientific research institution with wide scope of activities. The latest comprehensive accreditation identified as one of

The address of the corresponding author: Zdenek Dvorak 韧”zdenek.dvorak@fbi.uniza.sk its weaknesses the fragmentation of research and educational capacities and activities in some core fields of study, e.g. management, transport services. On the basis of its recommendations the accreditation authorities of the Faculty of Security Engineering of the University of Žilina (hereinafter FBI UNIZA) adopted a decision that the so far implemented programme "Transport in crisis situations " would gradually finish and the faculty 
would apply for accreditation of the new study programme in the research field of security services. In October 2015 the Accreditation Commission accredited the new study programme "Security and protection of critical infrastructure". The purpose of this paper is to state the basic terms in the field of security of systems and elements of critical infrastructure and its protection. We also wish to justify the need of education in fields of security management and protection of important infrastructure networks. An important part also is the brief presentation of the new study programme and present challenges for its future development and contribution to the society.

\section{THEORETICAL FOUNDATIONS OF SECURITY MANAGEMENT OF CRITICAL INFRASTRUCTURE}

New security threats, political and economical changes in the world as well as dynamic development of technologies are constantly bringing new security risks. Therefore it is necessary to constantly look for new ways how to protect (i.e. to secure the desired level of security) of people, property or a certain area as such. The issues of security and protection of so called critical infrastructure (hereinafter $\mathrm{Cl}$ ) should be perceived and solved in a complex way, especially due to the interconnectedness of individual important infrastructures. The efforts of the European Union (hereinafter EU) in this strategically important area aim to support cooperation among individual countries and create a consistent approach to the crucial problems of security management of important European infrastructure. The Slovak Republic (hereinafter SR) several years ago adopted legal standards (Law 45/2011) and measures leading to fostering the importance of $\mathrm{Cl}$ problems and securing the desired level of its security and protection.

\subsection{What is critical infrastructure}

It is a system that can be divided into fields and elements. The elements of critical infrastructure are assets, facilities, services and information systems whose disruption or destruction would have serious adverse consequences for performing economic and social functions of the state. The purpose of $\mathrm{Cl}$ protection is to maintain the quality of human life from the point of life, health, security and property protection as well as environment protection.

In other words, critical infrastructure is the part of national infrastructure, so important that its destruction under the influence of risk factors can cause a debilitating effect on society. The critical infrastructure is a part of the state security system. To understand all aspects of critical infrastructure areas it is necessary to be aware of the list of so called critical infrastructure sectors.

In most developed countries the main $\mathrm{Cl}$ sectors are considered - power engineering (nuclear power generation, electricity transmission, transportation and distribution of natural gas, transportation and processing of oil, heat generation and extraction of important raw materials), transport (road, railway, air and water), information and communication technologies (networks, data centres, controlling and information systems, carriers of important information, etc.). Among other important areas we can find water management, food security, financial sector, medical facilities and others.

\subsection{Vulnerability of systems and services of critical infrastructure}

How can the $\mathrm{Cl}$ subsystems and elements be disrupted, destroyed or temporarily/permanently disabled? The European Council Directive 2008/114/ES (European Directive 2008/111/ES) defined the term European critical infrastructure (hereinafter $\mathrm{ECl}$ ). To identify its elements for efficient managing of $\mathrm{ECl}$ security, it is necessary to define the types of attacks as well as the probability estimate of occurrence and their expected consequences.

- Anthropogenic influences - negative phenomena caused by human activity (e.g. terrorist attacks, hacker attacks, industrial accidents, human errors, etc.

- Natural influences - negative phenomena caused by natural processes (e.g. tectonic effects, meteorological risks related to the effects of extreme weather, risks related to slope movements, etc.

One of the most probable anthropogenic threats is a direct targeted armed attack carried out by 
armed terrorist groups, bomb attack - usually carried out by an individual or a small group. Another possibility is a cyber attack, designed to destroy or control computer systems. An important risk is the so called information operations attacks with the purpose to gain or abuse information, to influence processes based on information (e.g. to influence the system in a way that it appears fully functional but in fact it works with manipulated data). The authors were dealing with the problem of protection against the above mentioned types of attacks and related security risks within the APVV project solution no. 0471-10 "Critical Infrastructure Protection in Sector Transportation" (OKI 2010)

There are altogether 14 most probable types of natural threats - effects of extreme weather in European conditions. The most important meteorological effects and their consequences in the conditions of central Europe are: extreme precipitation, windstorms, river floods, heavy lighting storms, abundant snowfall, snow storms, freezing rain, extreme temperatures, forest fires. The authors of this paper are dealing with the problem of security risks related to negative effects of extreme meteorological conditions on functioning the $\mathrm{Cl}$ systems and services within the experimental project solution FP7 - RAIN „Risk Analysis of Infrastructure Networks in response to extreme weather" (RAIN, 2014).

In the conditions of the Slovak Republic there has not been created a generally accepted methodology for objective classification of individual infrastructure elements (especially the power generating, transportation and informationcommunication infrastructures) into the set of potential $\mathrm{Cl}$ elements. The authors are currently involved in this problem solution within the VEGA project no. 1/0240/15 "Process model of critical infrastructure safety and protection in the transport sector" (VEGA 2015).

Eventually, there is no precisely defined methodology for evaluating the criticality of important elements of infrastructure and their sensitivity for failure of other important infrastructures. The authors are dealing with this problem within the project that is being solved in the Czech republic under the title „RESILIENCE
2015 Dynamic Resilience of Interrelated Critical Infrstructure Subsystems" (RESILIENCE, 2015).

The term protection of critical infrastructure can be understood as (Novak 2011) a set of measures that have to be provided by the owner or building operator and have to be secured by the respective integrated rescue system units in order to ensure the desired functionality and performance of important infrastructure. The objective of the protection system of critical infrastructure should principally be minimizing the risk of eliminating a function, activity or service. (Seidl, \& Simak 2012).

Considering the information stated above, it is possible to define the aims of $\mathrm{Cl}$ protection as follows:

- to prevent intrusion into the building and prevent activities of unauthorized persons or groups,

- to decrease or prevent the security risk occurrence (terrorist attack, sabotage, extreme weather effects, etc.),

- to ensure operability of technology and usability of supplies,

- to secure operational safety and related security of residence of population or military forces in the vicinity of buildings. Adapted according to (Sventekova, Cicmancova, 2013).

Due to the reasons stated above, at FBI UNIZA a new programme "Security and protection of critical infrastructure "was accredited. Its main focus is security in the sectors of power engineering and transport. It also contains courses focusing on other sectors of critical infrastructure - especially information and communication technologies, water supply, medical infrastructure (Simak, 2012).

\section{CHARACTERISTICS OF THE STUDY PROGRAMME AT THE FACULTY OF SECURITY ENGINEERING}

One of the fields of tertiary education is the field of security and civil protection and crisis management. It is necessary to realize that civil protection is based on the principle of ensuring the security of an individual, community and society (Titko, Peterkova, Holla, 2013). In 2015 the 
Accreditation Commission confirmed the FBI UNIZA accreditation for bachelor and engineer degree programmes that focus on the field of security and protection of critical infrastructure. The study programme „Security and protection of critical infrastructure" is:

- unique in central Europe,

- multidisciplinary oriented, focusing on various types of infrastructure networks,

- based on the needs of practice,

- supported by the Slovak Ministry of Interior, Ministry of Transport, Construction and Regional Development and the Ministry of Economy,

- is primarily focused on the main ECl fields energy a transport.

\subsection{Structure and content of the curriculum}

To demonstrate the contents of the study programme we only provide a selection of the most important courses for our full-time bachelor's degree students and full-time engineer's degree students in the study program "Security and protection of critical infrastructure". Among the most important courses in the bachelor studies we rank:

- general courses e.g. Mathematics I. and II., Engineering geometry, Physics, Economics, Informatics, Logistics, Occupational safety and health, Basic mechanics I and II, Technical drawing, Management, Operational analysis, Managerial Statistics and others.

- profile subjects, e.g. Energy infrastructure, Transport infrastructure, Nuclear, chemical and biological protection, Civil protection, Production equipment and technologies in power engineering, Risk management, Crisis management, Topography, Cartography and geographic information systems, Transport equipment and technologies, Protection of critical infrastruture objects in the transport sector, Dangerous substances and articles, Protection of people and property and others.

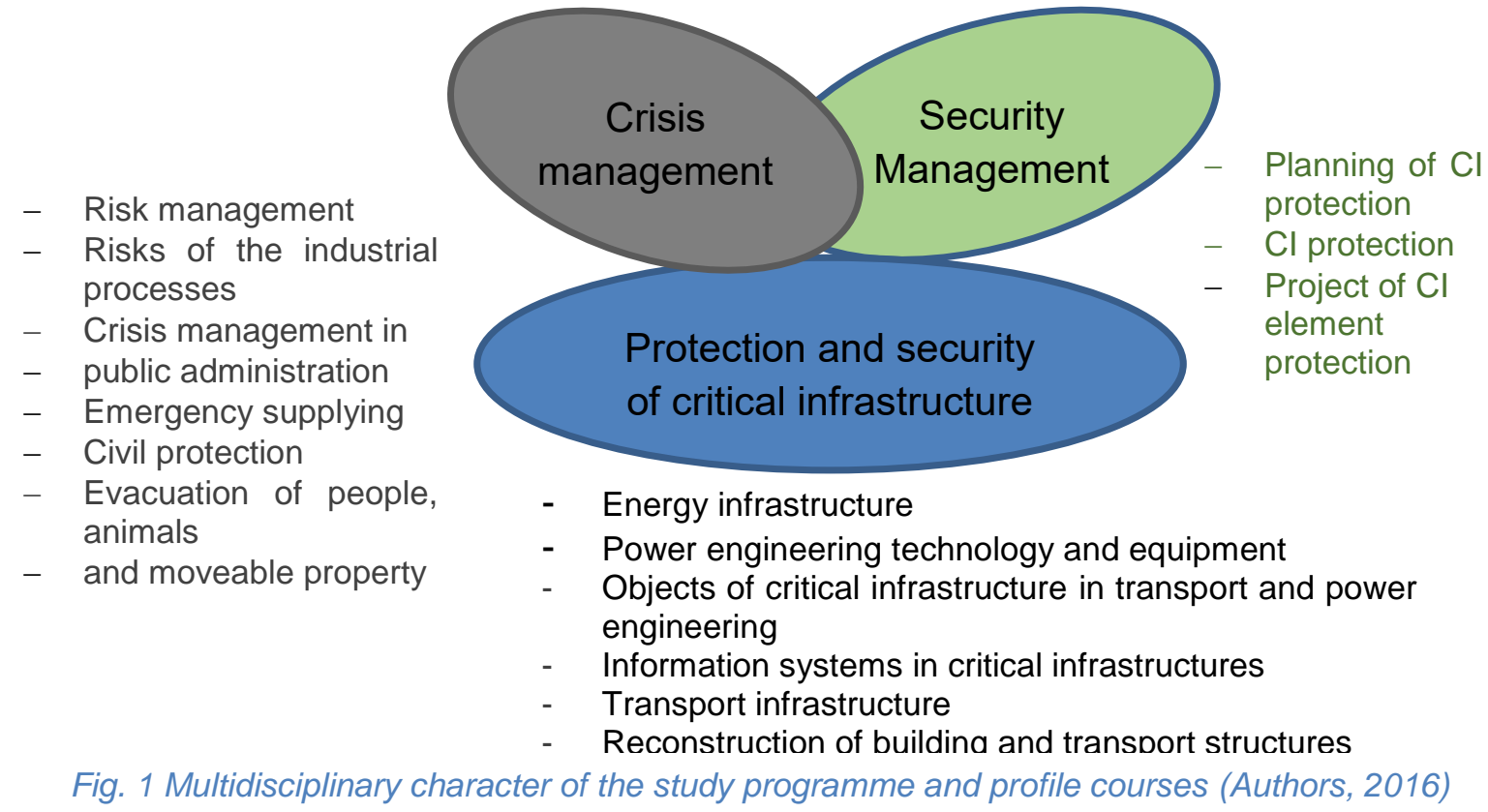

Among the most important courses in the engineer studies we rank:

- general courses, e.g. Stochastic Methods of Operational Analysis, Management Information Systems, Risks of industrial processes, Managerial Methods and Techniques, Forecasting and planning and others.

\begin{abstract}
profile subjects, e.g. Transport in crisis situations, Crisis management, Building and transport structures, Reconstruction of building structures, Planning of critical infrastructure protection, Controlling and information systems of critical infrastructure, Risk management of critical infrastructure, Project of $\mathrm{Cl}$ element protection and others.
\end{abstract}


The complete curriculum for both levels of study programme "Security and protection of critical infrastructure" is available on the faculty website.

The main advantage and a specific feature of the study programme especially is the intersection of of knowledge and skills from the fields of crisis and security management. The graduate's knowledge and skills are focused on risk management, security management and ways of securing protection of important structures (Documentation 2015).

\subsection{Graduate profile and employment opportunities}

To demonstrate the assumed knowledge and skills of graduates of our study programme, only the crucial parts of the engineer graduate profile will be provided.

The graduates of the $2^{\text {nd }}$ degree (master degree) will be able to identify possible threats and sources of risk in social, economic, natural, technical and technological processes, they will be able to analyze and comprehensively evaluate them as well as to propose procedures and application of methods and techniques of risk minimization. They will possess theoretical knowledge of critical infrastructure protection with specific focus on power engineering, transport and necessary basics of information and communication technologies. They will be able to propose and implement prevention measures, to monitor and analyze the development of risk and crisis factors, prepare the adequate response to the emerging crisis phenomenon, manage continuity in the functioning of critical infrastructure elements and to implement an efficient system recovery. The graduates should be able to forecast the development of social, economical, natural and technological processes, to apply the optimization procedures and other management tools to improve the efficiency of their operations. They will be provided with information on security management system of the state, on regional territorial units and their self-government. The graduate is a qualified expert in managing security and protection of:
- entities in the fields of power engineering, oil and natural gas production and distribution, heat industry, transport infrastructure management,

- entities that provide protection of important objects and systems of infrastructure,

- central state administration bodies (Ministry of Economy, Transport, Defense, Interior),

- expert teams active in protection of infrastructure networks.

\section{CONCLUSIONS}

The energy and transportation system of the region, state and the whole European area is a complex, interdependant structure, consisting of large number of infrastructures (energy production facilities, transmission systems, transport routes, information systems, terminals, etc.). This structure is of crucial importance for securing the vital functions of society. The fields of power engineering and transport are therefore considered the most important sectors of critical infrastructure in most developed countries worldwide.

The most topical and crucial problems of the new study program are:

- demographic crisis consequences (sharp drop in the number of university applicants),

- ignorance of the concept of critical infrastructure and its related issues in society, as a result the title of the study programme remains unknown for most potential applicants,

- the first study programme focused on $\mathrm{Cl}$ protection in the Central and Eastern Europe and related lack of opportunities to exchange experience and experts in the field,

- necessity to create the form and contents of new profile courses, especially for important areas of power engineering and information and communication technologies,

- lack of opportunities of subject-specific and practical cooperation with important energy companies and their experts for problems of security and protection of their company infrastructure (Vidrikova 2013). 
This paper was supported by projects VEGA č.1/0240/15

Process model of security and protection management of critical infrastructure in sector transport

\section{WORKS CITED}

Law No: č.45/2011 Z.z. about critical infrastructure

European Council Dierective 2008/114/ES, z 8.12.2008 o identifikácii a označení európskych kritických infraštruktúr a zhodnotení potreby zlepšit' ich ochranu, In: Úradný vestník Európskej únie, L 345/75-82, zo dňa 23.12.2008.

Novák, L. (2011): Kriticeskaja infrastruktura transporta $\vee$ Slovackoj respublike, In: Mechanics Transport Communications 3/2011, časopis Vysoká škola dopravy T.Kableskova Sofia, Bulharsko, ISSN 1312- 3823, s.X-149-X-155.

Seidl, M., Šimák, L.(2012): Protection of critical infrastructure. In: Logistics and transport, No 1(14)/2012, Wroclaw, ISSN 1734-2015, s. 81-102.

Sventeková, E., Čičmancová, S. (2013): Risk assessment of rail transport. In: Transport means 2013 : proceedings of the 17th international conference : October 24-25, 2013, Kaunas University of Technology, Lithuania. ISSN 1822-296X. Kaunas: Kaunas University of Technology, 2013. S. 228-231.

Šimák, L. a kol.(2012): Ochrana kritickej infraštruktúry v sektore doprava. 1.vyd., EDIS - vydavatel'stvo ŽU v Žiline, 2012, 180 s. ISBN 978-80-554-0625-1.

Titko, M., Peterková, A., Hollá, K.(2013): Vulnerability of Linear Transport Constructions of Critical Infrastructure and Comparison of Its Assessment Approaches. In: WSEAS 2013: 17th WSEAS International Conference on SYSTEMS (part of CSCC '13): Rhodes Island, July 16-19, 2013, Greece. ISBN 978-960-474-312-4.

Vidriková D., Boc, K.( 2013): Ochrana kritickej infraštruktúry. EDIS - vydavatel'stvo Žilinskej univerzity v Žiline, 2013. ISBN 978-80-554-0654-1.

Documentation (2015) Study programme - Security and Protection of Critical Infretructure, 2015, Fakulta bezpečnostného inžinierstva, Žilinská univerzita v Žiline. http://vzdelavanie.utc.sk/vzdelavanie/plany.php

Project docummentation OKI 2010 - APVV-0471-10 - Ochrana kritickej infraštruktúry v sektore doprava

Project docummentation RAIN 2014 - No. 608166 - Risk Analysis of Infrastructure Networks in Response to Extreme Weather

Projec documentation VEGA 2015 - VEGA 1/0240/15 Process model of security and protection management of critical infrastructure in sector transport

Project docummentation RESILIENCE 2015 Dynamic Resilience of Interrelated Critical Infrstructure Subsystems

Received for publication: $\quad$ 13.03.2016

Revision received: $\quad 14.05 .2016$

Accepted for publication: $\quad 10.06 .2016$

\section{How to cite this article?}

Style - APA Sixth Edition:

Dvorak, Z., Leitner, B., \& Mocova, L. (2016, July 15). Critical infrastructure safety and protection in Slovak Republic - Research and education. (Z. Čekerevac, Ed.) MEST Journal, 4(2), 49-55. doi:10.12709/mest.04.04.02.05 
Style - Chicago Sixteenth Edition:

Dvorak, Zdenek, Bohus Leitner, and Lenka Mocova. 2016. "Critical infrastructure safety and protection in Slovak Republic - Research and education." Edited by Zoran Čekerevac. MEST Journal (MESTE) 4 (2): 49-55. doi:10.12709/mest.04.04.02.05.

Style - GOST Name Sort:

Dvorak Zdenek, Leitner Bohus and Mocova Lenka Critical infrastructure safety and protection in Slovak Republic - Research and education [Journal] // MEST Journal/ ed. Čekerevac Zoran. Belgrade : MESTE, July 15, 2016. - 2 : Vol. 4. - pp. 49-55.

Style - Harvard Anglia:

Dvorak, Z., Leitner, B. \& Mocova, L., 2016. Critical infrastructure safety and protection in Slovak Republic - Research and education. MEST Journal, 15 July, 4(2), pp. 49-55.

Style - ISO 690 Numerical Reference:

Critical infrastructure safety and protection in Slovak Republic - Research and education. Dvorak, Zdenek, Leitner, Bohus and Mocova, Lenka. [ed.] Zoran Čekerevac. 2, Belgrade : MESTE, July 15, 2016, MEST Journal, Vol. 4, pp. 49-55. 